Огляди літератури, оригінальні дослідження, погляд на проблему

УДК 611.36:661.852:577.118-08

DOI

\title{
МОРФОЛОГІЯ ПЕЧІНКИ ПІД ВПЛИВОМ АЦЕТАТУ СВИНЦЮ ТА ЗА УМОВ КОРЕКЦІї МІКРОЕЛЕМЕНТАМИ (ОГЛЯД ЛІТЕРАТУРИ)
}

๑ю. О. Бельська

\section{Державний заклад «Дніпропетровська медична академія Міністерства охорони здоров'я України»}

РЕЗЮМЕ. Свинець характеризується політропністю дії на організм, викликає порушення кровотворення, дезорганізацію паренхіми і мікроангіоархітектоніки ембріональної печінки та виснаження запасів глікогену. На сьогоднішній день відомий ряд мікроелементів, які мають біоантагоністичні властивості по відношенню до свинцю, серед яких цинк, селен, кальцій та ін. Срібло і золото займають особливе місце серед розмаїття мікроелементів. Попередні дослідження виявили модифікуючий ефект срібла і золота в умовах свинцевої інтоксикації під час ембріогенезу. Однак органогенез печінки під впливом цитратів срібла і золота на тлі свинцевої інтоксикації вивчений недостатньо.

КЛЮчОВІ СЛОВА: ацетат свинцю, ембріон, фетальна печінка, цитрат срібла, цитрат золота.

Вступ. Для промислових областей особливо актуальною є проблема забруднення важкими металами, які небезпечно впливають на організм людини, змінюючи його властивості та функції. Важкі метали - це група хімічних елементів 3 властивостями металів і значною атомною вагою або щільністю. До важких металів належать кобальт, мідь, цинк, кадмій, ртуть, свинець. У всьому світі свинець відомий як природний токсичний елемент, який входить до складу земної кори. Тягучість цього металу, резистентність його до корозії, а також низька температура плавлення $\epsilon$ підставою для його використання у промисловості. Застосування металу у технічних потребах призвело до широкомасштабного забруднення навколишнього середовища і порушень громадського здоров'я на багатьох територіях земної кулі. На сьогоднішній день рівні свинцю перевищують гранично допустимі, особливо це стосується країн, що розвиваються $[1,2]$.

Мета дослідження - провести аналіз літературних джерел з впливу свинцю та мікроелементів на ембріон та печінку під час пренатального онтогенезу.

Основна частина. Свинець характеризується політропністю дії на організм та призводить до виникнення безлічі метаболічних розладів [3]. Надходження свинцю до внутрішнього середовища людини спричиняє спектр вісцеральних та скелетних мальформацій. Солі плюмбуму накопичуються у кістках, викликають їх пошкодження та розвиток остеопорозу [4]. Свинець порушує роботу нервової системи, нирок, печінки та кровотворної системи [5], токсично впливає практично на всі системи організму і викликає у них біохімічні зміни [6]. Сполуки свинцю мають різні шляхи потрапляння в організм, без змін мігрують між організмами та крізь плаценту, ніколи не метаболізуються та не втрачають свого токсичного ефекту, що встановлено в ранніх дослідженнях [7].
Народження здорових нащадків, здатних ефективно адаптуватися до умов навколишнього середовища, багато в чому залежить від становлення органів і систем в процесі ембріогенезу. У процесі вагітності жінки відчувають негативний вплив численних несприятливих факторів зовнішнього середовища, навіть не перебуваючи у шкідливих умовах праці. Вплив токсичних чинників протягом вагітності негативно позначається на процесах ембріогенезу. Відомо, що високі концентрації свинцю викликають виражені зміни як в організмі матері, так і її потомства. Свинець здатний проходити через гематоплацентарний бар'єр [8], більш того, в період вагітності спостерігається мобілізація свинцю, раніше депонованого в організмі жінки. Вагітні і діти особливо чутливі до свинцевого впливу. Дія високої концентрації свинцю під час вагітності викликає викидні, мертвонародження, передчасні пологи, низьку вагу при народженні та аномалії різних органів і систем плода [9-11]. Навіть низькі дози свинцю мають ембріотоксичний ефект, що проявляється у зниженні кількості живих плодів та збільшенні загальної ембріональної смертності [12]. Дослідження свідчать, що порушення вигину ембріона призводить до порушення ембріогенезу та органогенезу. В нормі на ранніх етапах розвитку хвіст ембріона завжди торкається мозкових пухирів, а сам ембріон не тільки зігнутий (флексія ембріона), але й скручений за повздовжньою віссю (торсія ембріона). Під впливом ацетату свинцю зменшується кут згинання ембріона та повністю відсутнє скручування ембріона при зовнішніх ідентичних показниках розвитку, таких як маса, розмір, рівень розвитку ока та бруньок кінцівок. При розтині матки вагітної самиці наприкінці вагітності ембріони малорухливі, мають ослаблений вигляд та гіперемію шкірних покривів, що $\epsilon$ результатом впливу свинцевої інтоксикації [13]. 
Огляди літератури, оригінальні дослідження, погляд на проблему

Одне з центральних місць у сучасних дослідженнях посідає виявлення морфологічних змін та вад розвитку, що виникають внаслідок дії важких металів, зокрема свинцю. У зв'язку з цим збільшується актуальність морфологічних досліджень морфології печінки в нормі та під впливом певних факторів. Печінка $\epsilon$ органом $з$ широким функціонально-метаболічним профілем, який першим приймає на себе удар при впливі солей важких металів, а саме свинцю. Плюмбум викликає хронічне запалення та пошкодження цього органа, що супроводжується підвищенням рівня печінкових трансфераз у відповідь на токсичний вплив [14]. Біологічні мембрани гепатоцитів, ендотелію, еритроцитів $\epsilon$ улюбленими мішенями для свинцю, ураження яких супроводжується явищами некрозу і гіпоксії в печінкових часточках [15]. Фетальна печінка привертає велику увагу дослідників, адже у внутрішньоутробний період вона виконує синтетичну та гемопоетичну функції $[16,17]$. Тобто у пренатальному періоді онтогенезу в ній паралельно відбуваються два гістогенетичні процеси. 3 одного боку, формується власне печінкова тканина, а з іншого - спостерігаються тяжі та осередки гемопоетичних клітин, які можуть давати початок всім росткам кровотворення. Ключову роль у регуляції цих процесів відіграє гетерогенна за клітинним складом строма зародкової печінки, яка забезпечує специфічне мікрооточення задля росту, дозрівання та диференціювання кровотворних і печінкових стовбурових клітин [18]. Наприкінці четвертого тижня ембріогенезу людини (у білого щура - 13 діб) печінка стає центром кровотворення, а невдовзі - найбільшим внутрішнім органом (у зародків людини -5-8 тижнів, у щурів14-16 діб) [19]. Не дивлячись на те, що жовчний міхур ніколи не розвивається у щурів, схожість окремих печінкових структур людини та цих тварин, особливо наприкінці ембріогенезу, робить останніх доброю експериментальною моделлю для вивчення нормального та аномального розвитку печінки [20]. Мікроскопічно печінка новонароджених щурят не має чіткої часточкової структури, сполучнотканинні прошарки практично не розвинуті, портальні зони не виявляються. При цьому центральна вена з еритроцитами, синусоїдні капіляри нерівномірно розширені і не мають чіткої радіальної орієнтації. Осередки з гемопоетичними клітинами, серед яких велика кількість належить до мегакаріоцитів, $\epsilon$ характерною морфологічною ознакою ембріональної печінки. Острівці кровотворення мають екстраваскулярну локалізацію. Гепатоцити не утворюють чітких радіально розташованих балок, вони формують звивисті ряди клітин без чіткої орієнтації. Кровотворення у печінці щурів зупиняється у перші тиж- ні постнатального онтогенезу [9] і тільки ближче до 30 доби постнатального розвитку можна спостерігати чітко сформовані печінкові часточки та печінкові балки [7]. Свинець, у свою чергу, викликає порушення кровотворення, дезорганізацію паренхіми і судинного компонента печінки [2022]. Судини мікроциркуляторного русла печінки щурів, матері яких отримували свинець під час вагітності, розширені, порівняно з контрольними зразками, та повнокровні. Вплив ацетату свинцю призводить до виснаження запасів глікогену [23]. Тривале надходження в організм малих доз свинцю призводить до альтерації паренхіматозних і стромальних компонентів печінки, що характеризуються розвитком дистрофічних, некробіотичних та деструктивних змін з поступово наростаючим порушенням мікроангіоархітектоніки. Таким чином, дія свинцю на систему мати - плід призводить до порушення нормального гістогенезу та органогенезу печінки, що проявляється у розширенні синусоїдних капілярів, лімфоцитарній інфільтрації в ділянці портальних зон, повнокрів'я центральних вен. Аналіз літературних даних про дію свинцю на формування та дозрівання печінки виявив типовий характер змін у структурній організації органа, що відрізняється лише у кількісному співвідношенні. Можна припустити, що спостережувана реакція не специфічна, а $\epsilon$ загальнобіологічною реакцією у відповідь на дію антропогенних факторів при взаємодії плода та материнського організму [9].

На сьогоднішній день відомі мікроелементи, яким притаманні біоантагоністичні властивості по відношенню до свинцю, серед них цинк, селен, кальцій тощо. Дослідження свідчать, що цинк, вступаючи у конкурентну взаємодію зі свинцем, мінімізує його шкідливий вплив, веде до зниження показників ембріолетальності, збільшення кількості живих плодів, веде до покращення біохімічних та гематологічних показників [24-26]. Широковідомим мікроелементом, який протидіє свинцю, є селен, який знижує акумуляцію свинцю у органах-мішенях, зменшує свинець-індукований оксидативний стрес та покращує загальний стан здоров'я [27]. Селен у комбінації з альфатокоферолом має антиоксидантні властивості, що проявляється у нівелюванні пошкодження печінкових клітин [14]. Зменшення надходження кальцію з продуктами харчування призводить до підвищеної акумуляції свинцю у кістковій тканині [28], саме тому населення, що проживає в умовах свинцевого забруднення, має звертати особливу увагу на дієту, збагачену кальцієм.

Срібло та золото займають особливе місце серед усього різноманіття мікроелементів. Срібло має широкий спектр антибактеріальних і анти- 
Огляди літератури, оригінальні дослідження, погляд на проблему мікотичних ефектів та чинить стимулювальний ефект на кровотворні органи [29, 30]. Золото використовується в терапії онкологічних захворювань, а також з метою діагностики та лікування ревматичних хвороб [31]. Попередні дослідження виявили модифікувальний ефект срібла та золота на тлі свинцевої інтоксикації протягом ембріонального періоду [12]. Введення цитратів срібла та золота в умовах свинцевої інтоксикації веде до збільшення кількості живих плодів, що обумовлено зниженням загальної та доімплантаційної смертності у порівнянні з групою свинцевої інтоксикації [32]. Цитрат срібла на тлі впливу свинцю проявляє компенсаторну дію на міокард [33]. Наноаквахелат золота зменшує ембріотоксичність

ацетату свинцю, що супроводжується зниженням ембріолетальності та підвищенням кількості живих ембріонів [12].

Висновки. Проаналізувавши дані літератури, що висвітлюють ефекти впливу свинцю і мікроелементів на організм ембріона та зокрема на фетальну печінку, ми виявили, що органогенез печінки під сумісним впливом цитратів срібла і золота на тлі свинцевої інтоксикації вивчений недостатньо.

Перспективи подальшого дослідження. Дослідження комбінованого впливу ацетату свинцю та цитратів срібла та золота $\epsilon$ актуальним завданням сучасної експериментальної медицини.

\section{ЛІТЕРАТУРА}

1. Meyer P. A. Global approach to reducing lead exposure and poisoning/P. A. Meyer, M. J. Brown, H. Falk // Mutation research/reviews in mutation research. - 2008. № 1. - P. 166-175.

2. Protective Effect of Naringenin Against LeadInduced Oxidative Stress in Rats / J. Wang, L. Yang, L. Lin [et al.] // Biological Trace Element Research. - 2012. P. 354-359.

3. Белецкая Э. Н. Гигиенические аспекты остеотропности свинца как фактора риска кальцийдефицитной патологии у человека (обзор литературы) /Э. Н. Белецкая, Н. М. Онул, О. В. Безуб // Медичні перспективи. 2014. - C. 130-138.

4. Campbell J. R. The association between blood lead levels and osteoporosis among adults-Results from the Third National Health and Nutrition Examination Survey (NHANES III) / J. R. Campbell, P. Auinger // Environmental Health Perspectives. - 2007. - № 7. - P. 1018-1022.

5. Anatomical and Histological Study of the Effect of Lead on Hepatocytes in Albino Rats / E. Metwally, F. Negm, R. El-din, E. Nabil // International Journal of Biomedical Materials Research. - 2015. - № 3. - P. 34-45.

6. Clinicopathological, histopathological and immunolog1ical studies on animals exposed to lead and cadmium under experimental conditions / A. Randa, M. Dawlat, A. Nariman [et al.] // New York Science Journal. - 2015. № 5. - C. 120-136.

7. Шубина О. С. Влияние свинцовой интоксикации на морфофункциональное состояние системы плацента-плод / О. С. Шубина, Ю. В. Киреева // Вестник Оренбургского государственного университета. 2008. - № 6. - C. 118-121.

8. Guo Y. Relationship between hematopoiesis and hepatogenesis in the midtrimester fetal liver characterized by dynamic transcriptomic and proteomic profiles / Y. Guo, X. Zhang // PLoS One. - 2009. - № 10. - C. 7641.

9. Вылегжанина Т. А. Влияние ацетата свинца на развитие печени крыс / Т. А. Вылегжанина // Оригинальные научные публикации. - 2015. - С. 44-48.

10. Transfer of lead via placenta and breast milk in human / P. J. Li, Y. Z. Sheng, Q. Y. Wang [et al.] // Bio-

medical and environmental sciences: BES. - 2000. № 2. - P. 85-89.

11. Скальный А. В. Биоэлементы и показатели эмбриональной смертности лабораторных крыс / А. В. Скальный, С. В. Залавина, С. В. Ефимов // Вестник Оренбургского государственного университета. - 2006. № 2. - C. 78-81.

12. Експериментальне дослідження модифікуючого впливу наноаквахелату цитрату золота на ембріотоксичність ацетату свинцю у щурів / В. Ф. Шаторна, В. І. Гарець, Е. М. Білецька [та ін.]. // Медичні перспективи. - 2014. - С. 12-17.

13. Романенко О. А. Морфометричні характеристики розвитку ембріонів щурів при дії ацетату свинцю / О. А. Романенко // Вісник проблем біології і медицини. - 2011. - № 1. - С. 212-215.

14. Protective Effects of Selenium and Alpha-Tocopherol against Lead-Induced Hepatic and Renal Toxicity in Oreochromis Niloticus / S. A.Elgaml, R. Khalil, A. Hashish, A. El-Murr // Journal of Aquaculture Research \& Development. -2015 . - № 6 .

15. Купша Е. И. Морфофункциональная характеристика стромального компонента печени белых мишей при длительном поступлении в организм малых доз свинца и фармакологической коррекции процесса / Е. И. Купша, В. В. Бондаренко // Инновации в науке. -2015 . - № 7.

16. Абдулкадыров К. М. Клеточный состав печени и селезенки в фетальном периоде / К. М. Абдулкадыров, В. А. Балашова // Клеточная трансплантология и тканевая инженерия. - 2008. - С. 46-48.

17. Морфологическое исследование клеточного состава фетальной печени человека / Ю. А. Петренко, Г. В. Грицай, Т. П. Говоруха [et al.] // Вісник проблем біології і медицини. - 2010. - № 2. - С. 177-183.

18. Паюшина О. В. Клеточный состав и регуляторные функции стромы зародышевой печени / О. В. Паюшина, Е. И. Домарацкая, В. И. Старостин // Цитология. 2012. - С. 369-380.

19. Карлсон Б. Основы эмбриологии по Пэттену / пер. с англ. - М. : Мир. - 1983. - Т. 1. - С. 357. 
Огляди літератури, оригінальні дослідження, погляд на проблему

20. Довгаль Г. В. Морфологічні зміни в розвитку печінки щурів при впливі ацетату свинцю та за умов корекції в пренатальному періоді / Г.В.Довгаль // Український морфологічний альманах. - 2014. - С. 42-44.

21. Романенко О. А. Імуногістохімічне дослідження печінки щурів в пізньому пренатальному періоді під впливом ацетату свинцю та за умов корекції / О. А. Романенко, Г.В.Довгаль, М.А.Довгаль // Вісник проблем біології і медицини. - 2012. - № 3. - С. 158-161.

22. Hepatotoxic effects of lead acetate in rats: histopathological and cytotoxic studies / Z. Haouas, I. Zidi, H. Hichri [et al.] // Journal of Cytology and Histology. 2014. - № 5. - P. 1-6.

23. Hegazy A. Evaluation of Lead Hepatotoxicity; Histological, Histochemical and Ultrastructural Study / A. Hegazy, U. Fouad // Forensic Medicine and Anatomy Research. - 2014. - № 3. - P. 70.

24. Біопротекторна дія цинку в макро- і наноаквахелатній формі на ембріогенез щурів за умови свинцевої інтоксикації / Е. М. Білецька, І. С. Чекман, Н. М. Онул [та ін.] // Медичні перспективи. - 2013. - С. 114-119.

25. El-Mehi A. E. Effect of Lead Acetate on the Thyroid Gland of Adult Male Albino Rats and the Possible Protective Role of Zinc Supplementation: A Biochemical, Histological and Morphometric Study / A. E. El-Mehi, S. A. Amin // Journal of American Science. - 2012. - № 7. P. 61-71.

26. Pattnaik N. Comparison of World Trade Center dust with zinc acetate and lead oxide combinations to determine damage to human lung cells / N. Pattnaik, A. DiLorenzo. // Journal of Toxicology and Environmental Health Sciences. - 2013. - № 4. - P. 60-65.
27. Бочкарева И. И. Взаимодействие селенсодержащих препаратов и тяжелых металлов в организме птицы / И. И. Бочкарева, Т. И. Бокова, К. Я. Мотовилов // Сибирский вестник сельскохозяйственной науки. 2009. - № 1. - С. 50-56.

28. Белецкая Э. Н. Остеотропность свинца как фактор риска патологии костной системы человека в условиях промышленного города / Э. Н. Белецкая, В. В. Околова // Екологія і природокористування. 2015. - № 19. - C. 192-192.

29. Colloidal silver fabrication using the spark discharge system and its antimicrobial effect on Staphylococcus aureus / D. C. Tien, K. H. Tseng, C. Y. Liao, T. T. Tsung // Medical engineering \& physics. - 2008. - № 8. - C. 948-952.

30. Pal S. Does the antibacterial activity of silver nanoparticles depend on the shape of the nanoparticle? A study of the gram-negative bacterium Escherichia coli / S. Pal, Y. K. Tak, J. M. Song // Applied and environmental microbiology. - 2007. - № 6. - P. 1712-1720.

31. Laser-induced explosion of gold nanoparticles: potential role for nanophotothermolysis of cancer / R. R. Letfullin, C. Joenathan, T. F. George, V. P. Zharov // Nanomedicine. - 2006. - № 4. - P. 473-480.

32. Анализ модифицирующего влияния цитратов золота, серебра и железа на эмбриотоксичность ацетата свинца в експерименте / В. Ф. Шаторная, В. Г. Каплуненко, И. С. Чекман [и др.] // Morphologia. - 2014. C. 99-103.

33. Нефьодова О. О. Модифікуюча дія цитрату срібла на кардіотоксичність ацетату свинцю в експерименті / О. О. Нефьодова. // Вісник проблем біології і медицини. - 2014. - С. 252-255.

\section{LIVER MORPHOLOGY UNDER THE INFLUENCE OF LEAD ACETATE AND IN CASE OF CORRECTION BY MICROELEMENTS (LITERATURE REVIEW)}

Olu. O. Belska

\section{Dnipropetrovsk Medical Academy}

SUMMARY. Lead has polytropic effect on the human body, which causes a disturbance of blood formation, disruption of parenchyma and microangioarchitectonics of fetal liver and depletion of glycogen. Trace elements with bioantagonistic properties to lead are known. They are zinc, selenium, calcium and others. Silver and gold have a special place among the variety of minerals. Previous studies have found a modifying effect of gold and silver in terms of lead intoxication during embryogenesis. However, liver organogenesis under the influence of silver and gold citrates on a background of lead intoxication is not studied enough.

KEY WORDS: lead acetate, embryo, fetal liver, silver citrate, gold citrate. 